\title{
MEDICAL CHECK-UP (MCU) MINI MOBILE DI RW 01 DESA MAJASETRA KECAMATAN MAJALAYA KABUPATEN BANDUNG
}

\author{
Aulia Nurfazri' $^{1)}$, Elis Susilawati' ${ }^{2}$, Wempi Budiana ${ }^{3)}$, Yani Mulyani ${ }^{4)}$ \\ Universitas Bhakti Kencana ${ }^{1)}$ \\ Universitas Bhakti Kencana ${ }^{2)}$ \\ Universitas Bhakti Kencana ${ }^{3)}$ \\ Universitas Bhakti Kencana ${ }^{4)}$
}

\begin{abstract}
ABSTRAK
Sindrom metabolik juga dikenal sebagai sindrom resistensi insulin. Prevalensi sindrom metabolisme secara global terus meningkat. Ada beberapa indikasi terkait sindrom metabolic yang patut diwaspadai. di antaranya adalah lingkar pinggang yang melebihi batas normal, tingginya tekanan darah, kadar trigliserida dalam darah, kadar glukosa dalam darah, dan rendahnya kadar HDL. Resiko terjadinya sindrom metabolik dipengaruhi oleh gaya hidup, stress yang berkepanjangan dan faktor genetic. Berdasarkan informasi yang diperoleh, kesadaran warga di Kp. Pangkalan RW.01 Desa Majasetra, Kecamatan Majalaya, Kabupaten Bandung akan kesehatan dan pola hidup sehat masih perlu ditingkatkan, oleh karena itu dilaksanakan Medical cek up (MCU) Mini Mobile untuk memberikan informasi terkait gejala sindrom metabolisme dan meningkatkan kesadaran masyarakat akan pentingnya pola hidup sehat.
\end{abstract}

Kata kunci: Sindrom Metabolisme, Medical Check Up

\begin{abstract}
Metabolic syndrome is also known as insulin resistance syndrome. The prevalence of metabolic syndrome globally continues to increase. There are several indications related to metabolic syndrome that need to be aware of. Among these are waist circumference that exceeds normal limits, high blood pressure, triglyceride blood levels, glucose blood levels, and low levels of HDL. The risk of developing metabolic syndrome is influenced by lifestyle, stress and genetic factors. Based on the information obtained, the awareness of residents in Kp. Pangkalan RW.01 Majasetra, Majalaya, Bandung on health and healthy lifestyle still needs to be improved, therefore a Mini Mobile Medical check up (MCU) is carried out to provide information related to symptoms of metabolic syndrome and increase public awareness of the importance of healthy lifestyle.
\end{abstract}

Kata kunci: Metabolic Syndrome, Medical Check Up

\section{PENDAHULUAN}

Sindrom metabolik juga dikenal sebagai sindrom resistensi insulin. Sindrom metabolism berkaitan dengan kondisi kelainan metabolisme termasuk intoleransi glukosa (diabetes tipe 2, gangguan toleransi glukosa, atau gangguan glikemia puasa), resistensi insulin, obesitas sentral, dislipidemia, dan hipertensi.

Angka kejadian sindrom metabolisme secara global terus meningkat. Prevalensi sindrom metabolism di dunia adalah 20-25\%. Berdasarkan data World Health Organization (WHO) prevalensi sindrom metabolik di Amerika Serikat mencapai 25\%. Di Indonesia, pada kelompok lanjut usia, prevalensi sindrom metabolic sebesar $14,9 \%$.

Sindrom metabolik seringkali tidak menunjukkan gejala yang spesifik, ada beberapa indikasi yang patut diwaspadai. di antaranya adalah lingkar pinggang yang melebihi batas normal, tingginya tekanan darah, kadar trigliserida dalam darah, kadar glukosa dalam darah, dan rendahnya kadar HDL. Resiko terjadinya sindrom metabolik dipengaruhi oleh gaya hidup (pola makan, olahraga, konsumsi alcohol, merokok), stress yang berkepanjangan dan faktor genetic. 
Pengabdian kepada masyarakat dengan tema Medical cek up (MCU) Mini Mobile ini dilaksanakan di Kp. Pangkalan RW.01 Desa Majasetra, Kecamatan Majalaya, Kabupaten Bandung. Berdasarkan informasi yang diperoleh, kesadaran warga akan kesehatan dan pola hidup sehat masih perlu ditingkatkan.

$$
\text { Adapun tujuan dari }
$$

dilaksanakannya kegiatan ini adalah untuk memberikan informasi terkait gejala sindrom metabolisme dan meningkatkan kesadaran masyarakat akan pentingnya pola hidup sehat.

\section{METODE PELAKSANAAN}

Metode pelaksanaan kegiatan adalah sebagai berikut :

1. Langkah pertama meminta izin kepada Ketua RT masing-masing untuk diadakan kegiatan Medical cek Up (MCU) Mini Mobile

2. Pembentukan Kader MCU yang terdiri dari 3 orang :

a. Pelatihan dasar untuk kader MCU tentang penyakit yang berhubungan dengan diabetes melitus, kegemukan, asam urat, tekanan darah dan kolesterol

b. Kader MCU mencari warga (responden) yang beresiko dan dan sudah menderita penyakitpenyakit yang sudah di sebutkan di atas. Dalam mencari responden di umumkan melalui arisan-arisan di masing-masing RT, pengajian ibu-ibu juga bapak-bapak atau juga langsung datang ke rumah warga.

c. Melakukan pencatanan warga yang akan berpartisipasi dalam MCU dari setiap RT di RW 01

d. Mengumpulkan responden di lokasi pemeriksaan untuk melakukan pemeriksaan pertama (dilakukan minggu ke 1) bagi warga yang bisa datang, bagi warga yang tidak bisa datang langsung di datangi ke rumahnya.

3. Pendampingan dan monitoring

Dalam pendampingan dan monitoring tersebut untuk melihat bagaimana gaya hidup atau kebiasaan makanan atau obat jika responden sebelumnya memang sudah mendapatkan obat yang dikonsumsi. Kemudian dilakukan pemeriksaan yang kedua (minggu ke 2 atau ke 3) pendampingan dan monitoring dilanjutkan kembali. Pemeriksaan dilakukan kembali pada minggu ke 4 .

4. Setiap responden akan mendapatkan kartu cek up yang berisi biodata responden, penyakit yang di derita, daftar makanan yang boleh dan tidak boleh untuk di konsumsi.

5. Kader MCU dapat melanjutkan atau menularkan pengetahuannya ke warga di sekitar mereka tinggal tentang pentingnya MCU sejak dini walaupun program tersebut telah selesai.

\section{HASIL DAN PEMBAHASAN}

Pengabdian kepada masyarakat berupa Medical cek up (MCU) ini dilaksanakan di Kp. Pangkalan RW.01 Desa Majasetra, Kecamatan Majalaya, Kabupaten Bandung. 


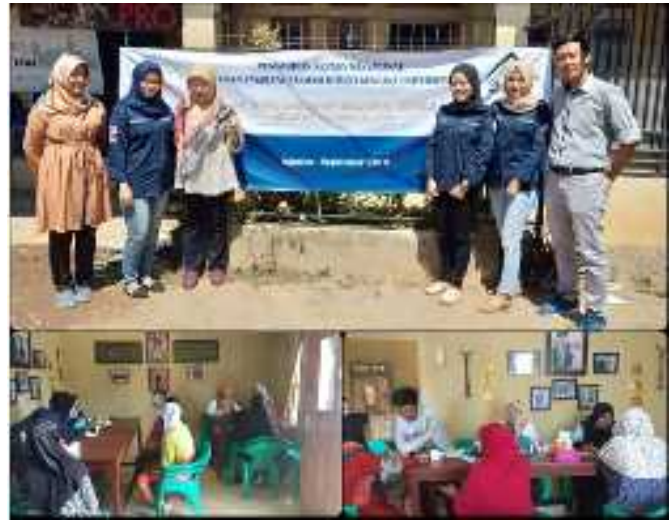

Gambar 1. Foto Kegiatan

Pemeriksaan dilaksanakan sebanyak dua kali dengan parameter kadar glukosa darah, kadar asam urat, tekanan darah, dan bobot badan dengan tujuan untuk melihat perubahan pola hidup masyarakat setelah penyuluhan.

Adapun hasil yang kami peroleh dari kegiatan tersebut adalah sebagai berikut :

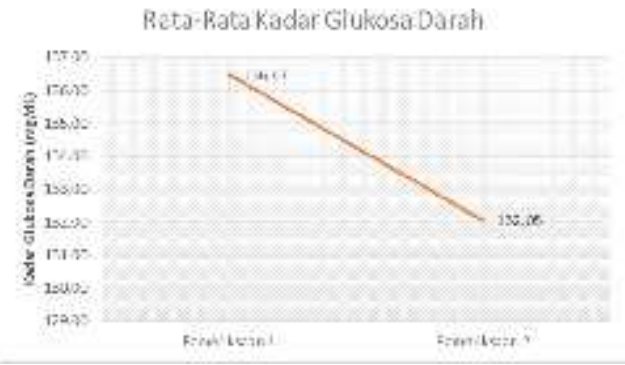

Gambar 2. Rerata Kadar Glukosa Darah

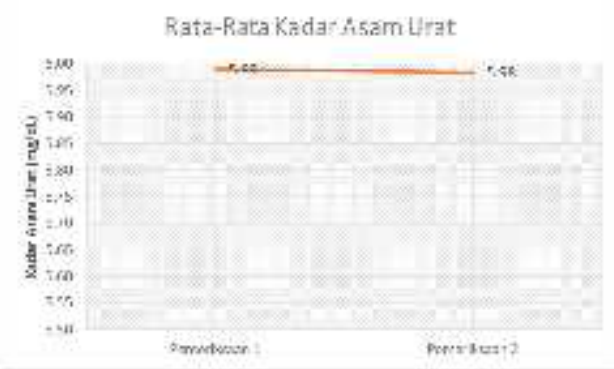

Gambar 3. Rerata Kadar Asam Urat

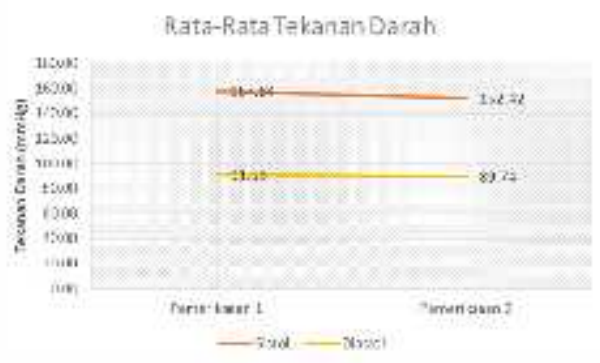

Gambar 4. Rerata Tekanan Darah

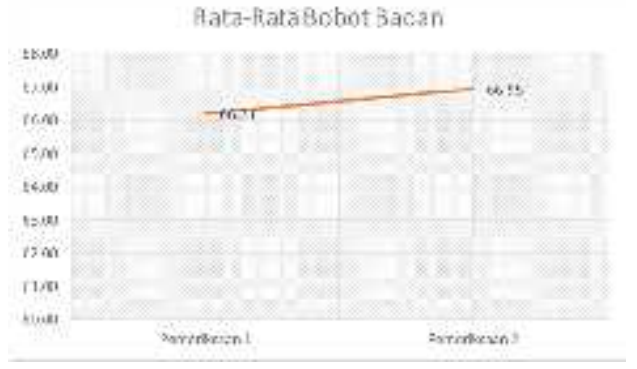

Gambar 5. Rerata Bobot Badan

Dari data berikut dapat dikatakan bahwa setelah diberikan penyuluhan terkait pola hidup sehat, masyarakat lebih memahami akan pentingnya pola hidup sehat dan mulai melaksanakan pola hidup sehat, hal ini terlihat dari adanya penurunan kadar glukosa darah, asam urat, dan tekanan darah namun pada bobot badan terjadi peningkatan.

\section{KESIMPULAN}

Dari hasil pelaksanaan Medical cek Up (MCU) Mini Mobile dapat disimpulkan bahwa kegiatan ini dapat memberikan informasi terkait gejala sindrom metabolisme kepada masyarakat dan meningkatkan kesadaran masyarakat akan pentingnya pola hidup sehat.

\section{REFERENSI}

Eckel, RH., Grundy, SM., Zimmet, PZ. (2005). The Metabolic Syndrome. The Lancet Vol.365.

Sudijanto K., Purwantyastuti., Dharmayanti UL., Ratna J., Yull KR., Besral. (2011). Prevalensi dan Determinasi Sindrom Metabolik Pada 
Kelompok Eksekutif di Jakarta dan Sekitarnya. Jurnal Kesehatan Masyarakat Nasional Vol.6.

Tri US., M Assaky B. (2016). Hubungan Sindrom Metabolik Dengan Penyakit Kardiovaskular. Jurnal Majority Vol.5. 